\title{
Optical dating of loessic hillslope sediments constrains timing of prehistoric rockfalls,
} Christchurch, New Zealand

\author{
Sohbati, Reza; Borella, Josh; Murray, Andrew Sean; Quigley, Mark; Buylaert, Jan-Pieter
}

Published in:

Journal of Quaternary Science

Link to article, DOI:

$10.1002 / j q s .2895$

Publication date:

2016

Document Version

Peer reviewed version

Link back to DTU Orbit

Citation (APA):

Sohbati, R., Borella, J., Murray, A. S., Quigley, M., \& Buylaert, J-P. (2016). Optical dating of loessic hillslope sediments constrains timing of prehistoric rockfalls, Christchurch, New Zealand. Journal of Quaternary Science, 31(7), 678-690. https://doi.org/10.1002/jqs.2895

\section{General rights}

Copyright and moral rights for the publications made accessible in the public portal are retained by the authors and/or other copyright owners and it is a condition of accessing publications that users recognise and abide by the legal requirements associated with these rights.

- Users may download and print one copy of any publication from the public portal for the purpose of private study or research.

- You may not further distribute the material or use it for any profit-making activity or commercial gain

- You may freely distribute the URL identifying the publication in the public portal 


\begin{abstract}
Developing a robust chronology for mass-movement events is of crucial importance to understanding triggering mechanisms and assessing hazards. We constrain the emplacement time of four palaeorockfall boulders near Christchurch, New Zealand, using optically stimulated luminescence (OSL) of quartz and infrared stimulated luminescence dating (IRSL) of K-feldspar from colluvial loess deposits underlying and upslope of individual boulders. The quartz OSL and K-feldspar pIRIR 290 ages are all consistent with the stratigraphy and in excellent agreement with each other, indicating that all the boulders that overlie the in-situ loess and oldest loess colluvium unit must have been emplaced $<13$ ka ago. A comparison of luminescence ages with cosmogenic ${ }^{3} \mathrm{He}$ surface-exposure ages from the surfaces of each boulder shows that two out of four boulders contain pre-deposition ${ }^{3} \mathrm{He}$ inheritance. Overall, the optical ages are consistent with both a prehistoric rockfall event at $\sim 8-6 \mathrm{ka}$ and a possible preceding event at $\sim 14-13 \mathrm{ka}$, although the temporal resolution of the time of emplacement of individual boulders is ca. 3-5 ka. This resolution is not limited by age uncertainties but rather by the stratigraphy. This study is the first to show a successful application of luminescence dating to New
\end{abstract}

\author{
${ }^{1}$ Technical University of Denmark, Centre for Nuclear Technologies, DTU-Nutech, DTU Risø Campus, DK-4000, \\ Roskilde, Denmark \\ ${ }^{2}$ Nordic Laboratory for Luminescence Dating, Department of Geoscience, Aarhus University, DTU Risø Campus, DK- \\ 4000, Roskilde, Denmark \\ ${ }^{3}$ Department of Geological Sciences, University of Canterbury, New Zealand \\ ${ }^{4}$ School of Earth Sciences, The University of Melbourne, Victoria 3010, Australia \\ *Corresponding author: resih@dtu.dk
}


Zealand colluvium loess and demonstrates the great advantage of a multi-technique approach in massmovement dating.

\section{Introduction}

Mass movements such as rockfalls, landslides and debris flows pose a serious hazard to human population and infrastructure in mountainous areas. At least 300 million people are exposed to these events worldwide (Dilley et al., 2005) and every year there are tens of reports of major mass movements around the world; these cause human fatalities (e.g. Bunce et al., 1998; Guzzetti et al., 2000; Baillifard et al., 2003; Massey et al., 2014), destroy buildings (e.g. Evans and Hunger, 1993; Yin et al., 2008) and damage transportation corridors (e.g. Hungr et al., 1999; Budetta, 2004). Determining the return frequency of such events is central to understanding their driving mechanisms and estimating their hazard. Earthquakes are one of the major causal mechanisms for slope failure, and rockfalls are, in turn, the most abundant type of landslide induced by earthquakes (Keefer, 1984). Coseismic rockfalls can thus be an indicator of past earthquakes and their timing may allow us to constrain earthquake recurrence intervals (Bull, 1996; Matmon et al., 2005; Mackey and Quigley, 2014). Unfortunately, establishing this timing is notoriously difficult due to the lack of reliable geochronological tools. Different techniques have been developed with the object of providing a chronology for past rockfall activity (Lang et al., 1999; Panek, 2014). These range from studying the degree of rock-surface weathering (e.g. Nesje et al., 1994) to lichenometry (e.g. Bull et al., 1994; Luckman and Fiske, 1995; Andre', 1997; McCarroll et al., 2001), dendrochronology (e.g. Stoffel, 2006), radiocarbon $\left({ }^{14}\right.$ C) dating (e.g. Stout, 1969; Bertolini, 2007), optically stimulated luminescence (OSL) dating (e.g. Balescu et al., 2007; Chapot et al., 2012) and cosmogenic nuclide (CN) surface-exposure dating (e.g. Rinat et al., 2014; Stock et al., 2014; Mackey and Quigley, 2014). All these techniques suffer from major uncertainties: most do not date the rockfall events directly and even $\mathrm{CN}$ dating cannot be easily applied because of problems resulting from inheritance of pre-event cosmogenic nuclides. Modern geochronology lays great emphasis on a multi-technique approach as this helps verify results from different techniques and reduce ambiguity in chronology. For example, using a novel approach of OSL dating directly applicable to rock surfaces, Chapot et al. (2012) determined the burial age of a fallen boulder as well as the underlying sediment in order to date a rockfall event that removed parts of a Barrier Canyon Style (BCS) rock art in southeastern Utah, USA. They supported the OSL ages by ${ }^{14} \mathrm{C}$ 
dating of a cottonwood leaf serendipitously found immediately between the boulder and underlying sediment (Chapot et al., 2012). In another example, Matmon et al. (2005) determined the age of three different rockfall events along the margins of the Dead Sea fault using a combination of CN dating of the fallen boulders and OSL dating of underlying deposits.

In South Island, New Zealand, earthquake-induced rockfalls are frequently embedded in loessic sediments (Heron et al., 2014); direct CN dating (Mackey and Quigley, 2014) and robust chronologies for loess accumulation and remobilization can thus be used to constrain the timing of these rockfalls. Luminescence is widely used to date loessic materials around the world (Roberts, 2015 and references therein) but luminescence dating of loess from South Island is perceived to be challenging (e.g. Almond et al., 2007). This perception is mostly based on studies using thermoluminescence (TL) and infrared stimulated luminescence (IRSL) of polymineral fine grain (i.e. 4-11 $\mu \mathrm{m}$ ) fractions from loess deposits in Westland, Southland and Canterbury (Berger et al., 2001a,b, 2002). The ages obtained have been reported to be anomalously young or old with low precision and in some cases in stratigraphically reversed sequence (Almond et al., 2001, 2007). The undesirable luminescence characteristics have been attributed to the highly weathered nature of these sediments and the dominance of albites compared to K-rich feldspars (Berger et al., 2001a; Almond et al., 2001). With technical and instrumental developments in luminescence dating techniques, later studies have reported more reliable ages for loessic material from the South Island even though some age inconsistencies, mainly attributed to anomalous fading of IRSL signals from K-feldspars, still occurred (Litchfield and Lian, 2004; Preusser et al., 2005). There have been few successful studies utilizing optically stimulated luminescence (OSL) dating of quartz (Holdaway et al., 2002; Rowan et al., 2012), probably due to reports on low OSL signal intensities and large changes in sensitivity (e.g. Preusser et al., 2006); none of these attempted to date loess. We are unaware of any prior attempts to (i) use 'paired' quartz OSL and K-feldspar IRSL dating to rigorously test the reliability of luminescence ages from New Zealand sediments, (ii) apply luminescence dating to larger grain size (i.e. $>11 \mu \mathrm{m}$ ) fractions of loess from the South Island, and (iii) apply luminescence dating to a steep, high-energy hillslope containing both in-situ and colluvial (reworked) loessic sediments.

In this study, we use coarse-grained quartz OSL and K-rich feldspar IRSL signals to date loessic deposits south of Christchurch, New Zealand (Fig. 1a). We show that these techniques provide 
consistent and robust sediment chronologies and give confidence in the results even in such challenging depositional environments. These loess deposits host numerous palaeorockfall boulders that have previously been dated by cosmogenic ${ }^{3} \mathrm{He}$ (Mackey and Quigley, 2014), enabling cross-validation of our optical ages with independent age control. The new luminescence ages allow us to refine the timing of palaeorockfall emplacement in an area of high rockfall hazard (Massey et al., 2014). This study and that of Borella et al. (in review) represent the first use of luminescence dating to refine palaeorockfall chronologies in New Zealand and one of the first to apply this technique globally (Matmon et al., 2005; Chapot et al., 2012).

\section{Site description and geological context}

The study site (Rapaki Study Site) is located in the Port Hills of southern Christchurch, nearby the village of Rapaki on Banks Peninsula (Fig. 1a,b). It is a steep ( 20-25 ) grassy slope (Fig. 1b) composed of in-situ loess deposits, overlying large basaltic rockfall boulders, and loessic colluvium deposits that contain basaltic clasts. A large number of boulders ( $>650)$ were dislodged from the steep source cliff upslope of the Rapaki Study Site during moment magnitude 6.2 and 6.0 earthquakes in Christchurch in 2011 (Fig. 1b). The palaeorockfall boulders identified on the same slope (Fig. 1b, c) have the same morphology, lithology, and similar spatial distribution as modern boulders and imply that similar earthquakes are likely to have been responsible for past rockfall activity (Mackey and Quigley, 2014; Borella et al., 2016, in review).

The loessic colluvium deposits have been remobilized by hillslope erosion and deposited downslope (Fig. 1c). Stratigraphic boundaries between in-situ and colluvial units (Fig. 1c) have been distinguished on the basis of textural, compositional, and grain-size variations (Borella et al., in review). Palaeosols have been identified in the loess colluvium and the top of the most recent colluvium contains an Ahorizon (Borella et al., in review). The slope geomorphology on the interfluve considered here consists of numerous rills and channels (Fig. 1b) that primarily originate from collapsed tunnel gullies, and sedimentary wedges formed upslope of boulders. More detailed geomorphic and stratigraphic data for the study site are available in Borella et al. (2016, in review). 
The source of the loess has been attributed to the proximal floodplains of the Waimakariri River (Fig. 1a) (Griffiths, 1973), which primarily transports weathered Cretaceous greywacke from the Southern Alps out into the Canterbury Basin (Villasenor et al., 2016). The basaltic source rock immediately upslope of the Rapaki Study Site is not a likely source because of the absence of quartz and low abundance of K-feldspar in the source rock.

Constraints on the timing of regional loess accumulation consist of previous ${ }^{14} \mathrm{C}$, optical dating, and tephrochronology at other study sites on Banks Peninsula (Fig. 1a) (Griffiths, 1973; Almond et al., 2007) and cosmogenic ${ }^{3} \mathrm{He}$ dating of palaeorockfall boulders overlying the in-situ loess (Mackey and Quigley, 2014). In-situ loess at the Rapaki Study Site has been correlated to the Birdlings Flat loess (Borella et al., in review). Intercalated volcanic ash within the Birdling's Flat loess (Fig. 1a) has been attributed to the 26,500 cal. yr BP Kawakawa Tephra (Almond et al., 2007). Humic acid from the uppermost identified palaeosol near the top of a section of correlative loessic units yielded a ${ }^{14} \mathrm{C}$ age of $17,450 \pm 2,070 \mathrm{cal}$. years B.P. (Griffiths, 1973). Almond et al. (2007) obtained a feldspar IRSL age of $17,300 \pm 1,000$ cal. years B.P. from near the top of the sequence. They interpreted feldspar IRSL ages to be underestimates, and suggested loess accumulation initiated prior to ca. $30,000{ }^{14} \mathrm{C}$ yr BP (ca. 35,000 cal. yr BP). Mackey and Quigley (2014) used cosmogenic ${ }^{3} \mathrm{He}$ surface-exposure dating to determine the emplacement time of 19 prehistoric rockfall boulders overlying the in-situ loess. The apparent surface-exposure ages ranged from 6 to $70 \mathrm{ka}$ with most ages between 6 and $20 \mathrm{ka}$; age concentrations at ca. 6-8 ka and $\sim 12-14 \mathrm{ka}$ were interpreted to reflect surface-exposure ages and older ages were attributed to pre-depositional inheritance (Fig. 1d). Borella et al. (2016, in review) obtained

${ }^{14} \mathrm{C}$ dates from charcoal within the uppermost layers of the reworked colluvial loess of $\sim 1660-1880$ A.D. $(2 \sigma)$. The in-situ loess at the Rapaki Study Site is thus conservatively attributed to deposition beginning before ca. $30 \mathrm{ka}$ and ending before ca. 6-13 ka, while the majority of reworked colluvial loess is attributed to deposition after ca. 6-13 ka and prior to 1660-1880 A.D.

\section{Sampling, laboratory preparation and analytical facilities}

Sampling for optical dating was targeted at five palaeorockfall boulders; three with credible exposure ages of $<13 \mathrm{ka}$ in stratigraphic order with the expected post-LGM depositional age of 17-13 ka for the underlying loess and two with exposure ages of $>20 \mathrm{ka}$. Thirteen OSL samples were collected by 
hammering metal tubes (5 cm diameter and $15 \mathrm{~cm}$ length) into freshly cleaned trench walls: (i) 8 samples from loess and loess colluvium deposits underlying the boulders, and (ii) 5 samples from reworked loess colluvium that accumulated behind the boulders after their emplacement on the hillslope (Fig. 1c, e). The samples underlying the boulders should predate their emplacement and thus give a maximum boulder emplacement age, whereas the accumulated deposits upslope of the boulders should postdate their deposition and so provide a minimum boulder emplacement age (Fig. 1e); by dating these samples we should be able to constrain the time window during which each boulder must have been put in place and thus determine the age of the responsible rockfall event.

Sediment was removed from sampling tubes under low level orange light and potentially light-exposed material from the outer ends of the tubes discarded; sediment from the middle of the tubes was then wet sieved to $40-63 \mu \mathrm{m}$. The grains were treated with $10 \% \mathrm{HCl}$ to remove carbonates and $10 \% \mathrm{H}_{2} \mathrm{O}_{2}$ to dissolve any reactive organic material. They were then etched with 10\% HF for 40 min to remove any alpha-irradiated surface layer and weathering products and coatings, followed by $10 \% \mathrm{HCl}$ for 20 min to remove any fluoride contamination. The K-rich feldspar fractions were then separated in a waterbased heavy liquid solution $\left(\rho=2.58 \mathrm{~g} . \mathrm{cm}^{-3}\right.$; Fastfloat). The quartz grains were further treated with hydrofluorosilicic acid for 2 weeks, followed by $10 \% \mathrm{HCl}$.

All luminescence measurements were carried out using a Risø TL/OSL reader (model TL-DA 20), with blue light stimulation $\left(\lambda=470 \mathrm{~nm}, \sim 80 \mathrm{~mW} . \mathrm{cm}^{-2}\right)$ and photon detection through a 7.5-mm Hoya U-340 glass filter for quartz, and infrared stimulation $\left(\lambda=875 \mathrm{~nm}, \sim 135 \mathrm{~mW} \cdot \mathrm{cm}^{-2}\right)$ and photon detection through a Schott BG39/BG3 filter combination (2 and $3 \mathrm{~mm}$, respectively) for K-feldspar (BøtterJensen et al., 2010). Beta irradiations used a ${ }^{90} \mathrm{Sr} /{ }^{90} \mathrm{Y}$ source mounted on the reader and calibrated for both discs and cups using 180-250 $\mu \mathrm{m}$ calibration quartz grains (Hansen et al., 2015). Grains were mounted as large ( $\sim 9 \mathrm{~mm}$ diameter for quartz) or medium ( $\sim \mathrm{mm}$ diameter for feldspar) aliquots in a monolayer using silicone oil on 9-mm-diameter stainless steel discs (quartz) or cups (feldspar). The heating rate was $5^{\circ} \mathrm{C} . \mathrm{s}^{-1}$ throughout. All thermal treatments and stimulations at temperatures higher than $200^{\circ} \mathrm{C}$ were carried out in nitrogen atmosphere, and a pause of $5 \mathrm{~s}$ was inserted before stimulation to allow all grains to reach the measurement temperature. Five empty channels were inserted before and after the stimulation to monitor any isothermal TL signals. 


\section{Dosimetry}

Radionuclide concentrations $\left({ }^{238} \mathrm{U},{ }^{226} \mathrm{Ra},{ }^{232} \mathrm{Th}\right.$ and $\left.{ }^{40} \mathrm{~K}\right)$ were measured using high-resolution gamma spectrometry on sediment collected from around the OSL sample tube. Approximately $50 \mathrm{~g}$ of sediment was dried at $50^{\circ} \mathrm{C}$, pulverized and homogenized, and then heated to $450^{\circ} \mathrm{C}$ for $24 \mathrm{~h}$ to remove any organic matter. The material was then cast in wax to prevent radon loss and to provide a reproducible counting geometry. Samples were stored for at least three weeks to allow ${ }^{222} \mathrm{Rn}$ to reach equilibrium with its parent ${ }^{226} \mathrm{Ra}$ before being measured on a high-purity Germanium detector for at least $24 \mathrm{~h}$. Details of the gamma spectrometry calibration are given in Murray et al. (1987). The internal beta dose rate activity from ${ }^{40} \mathrm{~K}$ was calculated based on an assumed effective potassium content of $12.5 \pm 0.5 \%$ (Huntley \& Baril, 1997), and the beta contribution from ${ }^{87} \mathrm{Rb}$ was calculated assuming a ${ }^{87} \mathrm{Rb}$ content of $400 \pm 100$ ppm (Huntley \& Hancock, 2001). For K-feldspar, a small internal alpha contribution of $0.10 \pm 0.05 \mathrm{~Gy} \mathrm{ka}^{-1}$ from internal ${ }^{238} \mathrm{U}$ and ${ }^{232} \mathrm{Th}$ was assumed included in the dose rates, based on from ${ }^{238} \mathrm{U}$ and ${ }^{232} \mathrm{Th}$ concentration measurements by Mejdahl (1987). For quartz, an internal dose rate of $0.010 \pm 0.002 \mathrm{~Gy} \mathrm{ka}^{-1}$ was assumed (Vandenberghe et al., 2008). The radionuclide concentrations were converted to dose rate data using the conversion factors from Guérin et al. (2011). The contribution from cosmic radiation to the dose rate was calculated following Prescott and Hutton (1994), assuming an uncertainty of 5\%. The long-term water content (expressed as a percentage of dry weight) was assumed to be similar to the modern water content. Water content, radionuclide concentrations and dry, infinite-matrix beta and gamma dose rates are summarized in Table 1.

\section{Luminescence characteristics}

\subsection{Quartz}

Quartz is the most widely used dosimeter in luminescence dating and the reliability of the quartz OSL single-aliquot regenerative-dose (SAR) protocol (Murray and Wintle, 2000) for dose determination is well-established (e.g. Murray and Olley, 2002). All the OSL measurements were performed at $125^{\circ} \mathrm{C}$ for $40 \mathrm{~s}$. A high-temperature blue-light stimulation at $280^{\circ} \mathrm{C}$ was also carried out for $40 \mathrm{~s}$ at the end of each cycle to minimize the residual signal transfer between different cycles (Murray and Wintle, 2003). Signal intensities were calculated using the initial $0.32 \mathrm{~s}$ of the signal, less an immediate background 
derived from the following $0.8 \mathrm{~s}$. An early background subtraction was selected to minimize the contribution of the more difficult to bleach and more thermally unstable medium and slow components to the net signal (Jain et al., 2003; Li and Li, 2006; Cunningham and Wallinga, 2010).

For all samples, the purity of quartz extracts was examined by measuring the OSL signal from three aliquots from each sample with and without prior infrared stimulation at room temperature for $100 \mathrm{~s}$. The ratio of the two OSL signals, the so-called OSL infrared (IR) depletion ratio, was then calculated for each aliquot (Duller et al., 2003). The resulting average OSL IR depletion ratio was 0.974 \pm 0.012 $(n=39)$, implying that any feldspar contamination of our quartz luminescence signals is negligible. Quartz extracts from all the samples were sensitive and the OSL signal was dominated by fast component (Fig. 2).

The performance of our quartz OSL SAR protocol was verified using both natural and dose-recovery preheat-plateau tests. The natural preheat-plateau test was carried out to investigate the dependence of equivalent dose $\left(D_{e}\right)$ on preheat temperature. Twenty-four aliquots of quartz from one of the samples were sorted in groups of three. Each of the eight groups was then treated with a different preheat temperature (between 160 and $300^{\circ} \mathrm{C}$ for $10 \mathrm{~s}$, with temperature increasing in $20^{\circ} \mathrm{C}$ steps). The temperature of the preheat treatment with immediate cooling after the test dose (the so called cut-heat temperature) was chosen to be $20^{\circ} \mathrm{C}$ lower than the preheat temperature. From Fig. $3 \mathrm{a}$ it can be seen that there is no obvious dependence of $\mathrm{D}_{\mathrm{e}}$ on preheat temperature between 160 and $300^{\circ} \mathrm{C}$.

For the dose-recovery preheat-plateau test, twenty-four fresh aliquots were stimulated twice at room temperature for $100 \mathrm{~s}$ using blue LEDs to fully reset the natural OSL signals. A pause of $1 \mathrm{ks}$ was inserted between the two stimulations to allow for any charge trapped in shallow refuge traps (especially that associated with the $110^{\circ} \mathrm{C}$ TL peak) to decay and subsequently partly refill the OSL trap prior to the second stimulation. The aliquots were then given a dose of $\sim 36 \mathrm{~Gy}$ and measured in a similar manner as in the natural preheat-plateau test. Fig. $3 \mathrm{~b}$ summarizes the measured-to-given dose ratios at different preheat temperatures. It appears that the dose recovery ratio is poor for low preheat temperatures $\left(<240^{\circ} \mathrm{C}\right.$ ) but is satisfactory (within $10 \%$ of unity) for the $240-280^{\circ} \mathrm{C}$ interval. The closest ratio to unity is $0.98 \pm 0.06(\mathrm{n}=3)$ at $260^{\circ} \mathrm{C}$, showing that a known laboratory dose absorbed before any thermal pretreatment can be accurately measured at this preheat temperature. Accordingly, a 
preheat temperature of $260^{\circ} \mathrm{C}$ (for $10 \mathrm{~s}$ ) and a cut-heat temperature of $240^{\circ} \mathrm{C}$ for $(0 \mathrm{~s})$ were selected for all quartz OSL $D_{e}$ measurements. A summary of the $D_{e}$ values and calculated ages is given in Table 1.

\subsection{K-rich feldspar}

K-feldspar is an alternative dosimeter in luminescence dating. However, its application has been hampered because K-feldspar IRSL signals are usually not stable with time (e.g. Huntley and Lamothe, 2001; Spooner, 1994; Wallinga et al., 2007). It is now broadly accepted that this athermal loss of signal, commonly called as anomalous fading, is due to the tunneling of electrons from thermally stable traps to nearby recombination centers (Jain et al., 2015). The presence of anomalous fading results in age underestimations (Aitken 1985), however the use of K-feldspar as dosimeter in luminescence dating has been increasing rapidly over the last few years since the recognition of the more stable infrared (IR) signals measured after a low temperature IR stimulation, the so-called post-IR IRSL signals (pIRIR) (Thomsen et al., 2008; Buylaert et al., 2009). We used a pIRIR 290 SAR protocol to measure the K-feldspar fractions from all the samples (Thiel et al., 2011). A preheat treatment of $320^{\circ} \mathrm{C}$ was applied for $60 \mathrm{~s}$ after natural, regenerative and test doses. The first IR stimulation at $50^{\circ} \mathrm{C}$ (IR50) was followed by a second IR stimulation at $290^{\circ} \mathrm{C}$ (pIRIR290). A high-temperature stimulation at $325^{\circ} \mathrm{C}$ was also performed at the end of each SAR cycle to minimize signal carry-over to the next cycle. All IR stimulations were carried out for $100 \mathrm{~s}$ and the full protocol is given in Table 2. The first second of stimulation less a background from the last ten seconds was used for all calculations.

In order to verify the reliability of the measurement protocol, a dose-recovery test was carried out by adding different known laboratory doses to the natural dose of the youngest sample. The largest added dose was selected in a way so that the total dose is close to the pIRIR $290 \mathrm{D}_{\mathrm{e}}$ of the oldest sample. As it can be seen from Fig. 4 , while the $\operatorname{IR}_{50}$ dose recovery ratio is poor $(\sim 0.8)$, the pIRIR 290 dose recovery is satisfactory (within $10 \%$ of unity) over the entire dose range in our samples (Fig. 4). Similar low dose recovery ratios have been observed for the $\mathrm{IR}_{50}$ signal measured as a part of the pIRIR 290 protocol (e.g. Buylaert et al., 2012; Schatz et al., 2012; Tsukamoto et al., 2013; Murray et al., 2014). It has been argued that this may be due to a trapping sensitivity change caused by the stringent preheating (here $320^{\circ} \mathrm{C}$ for $60 \mathrm{~s}$ ) of the sample prior to measuring the natural $\mathrm{IR}_{50}$ signal (Wallinga et al., 2000). Kars et al. (2014a) show that this sensitivity change cannot be detected through test dose responses in the SAR 
protocol, and thus may result in an invalid equivalent dose estimation. We therefore do not use the $\mathrm{IR}_{50}$ equivalent doses for age calculation. Instead, we only use these values in the discussion of incomplete bleaching (see section 6).

\subsubsection{Anomalous fading}

To measure the stability of the IRSL signals in our samples, an anomalous fading test was carried out on the same aliquots as used for $D_{e}$ determination. Anomalous fading is usually quantified by the ' $g$ 'value, which is the fractional loss of signal during a storage period of one decade of time, where the storage periods are expressed as decades relative to the laboratory irradiation time (Aitken 1985: appendix F). Three aliquots from each sample were measured to evaluate the ' $g$ '-value using SAR cycles (Table 2), following Auclair et al. (2003). Each aliquot was given a regenerative dose close to the sample-averaged pIRIR $_{290}$ equivalent dose and a test dose equal to $50 \%$ of the regenerative dose was used. The ratios of regenerated signals $\left(L_{x}\right)$ to test dose signals $\left(T_{x}\right)$ were measured repeatedly, with time delays of $\sim 0.22 \mathrm{~h}\left(\mathrm{IR}_{50}\right)$ and $\sim 0.27 \mathrm{~h}\left(\mathrm{pIRIR}{ }_{290}\right)$ for prompt measurements, and $12 \mathrm{~h}$ for delay measurements. The 'g'-values were calculated using equation 4 of Huntley and Lamothe (2001) and normalized to a measurement delay time $\left(\mathrm{t}_{\mathrm{c}}\right)$ of 2 days after irradiation (Fig. 5).

Fading rates showed no trends with depth or depositional environment (i.e. loess/(reworked) colluvium loess). We therefore combined data of all the samples and obtained mean $\mathrm{g}_{2 \text { days }}$ values of $0.7 \pm 0.8$ and $0.9 \pm 0.3 \%$ /decade $(n=39)$ for the $I_{50}$ and $\mathrm{pIRIR}_{290}$ signals, respectively. Several studies have documented similar fading rates of $\sim 1 \%$ /decade for the IRIR $_{290}$ signal, while the $\mathrm{IR}_{50}$ signal usually shows higher laboratory fading rates (e.g. Stevens et al., 2011; Roberts, 2012; Roskosch et al., 2012; Tsukamoto et al., 2013; Schatz et al., 2012). It has been suggested that such low fading rates (i.e. $<1.5 \%$ /decade) are most likely an artefact of the measurement procedure and do not accurately reflect the signal instability in nature (e.g. Thiel et al., 2011; Buylaert et al., 2012; Roberts, 2012). The feldspar ages were not corrected for apparent laboratory fading.

\subsubsection{Residual dose}

Post-IR IRSL signals are known to be difficult to bleach as there remains a residual dose even after prolonged exposure periods in daylight or solar simulator (e.g. Buylaert et al., 2011; Reimann and 
Tsukamoto, 2012; Lowick et al., 2012; Roberts, 2012; Li et al., 2013; Kars et al., 2014b). In order to determine the size of this residual dose in our samples we followed two different approaches. In the first method, 24 aliquots from the youngest sample were bleached in groups of three for different lengths of time (from 1 to $512 \mathrm{~h}$, increasing by powers of 2) using an artificial daylight spectrum (Hönle SOL2 solar simulator) approximately six times more intense than full sunlight. The $\mathrm{IR}_{50}$ and pIRIR $_{290}$ residual doses were then measured in the usual manner (Table 2). For both signals the residual doses decrease slowly with bleaching time and appear to reach a constant after $64 \mathrm{~h}$ of bleaching (Fig. 6). The average $\operatorname{IR}_{50}$ and $\mathrm{pIRIR}_{290}$ residual doses after an exposure time of $64 \mathrm{~h}$ are $1.24 \pm 0.14 \mathrm{~Gy}(\mathrm{n}=6)$ and $6.15 \pm 0.10 \mathrm{~Gy}(\mathrm{n}=6)$, respectively.

Sohbati et al. (2012) reported a correlation between the $\mathrm{IR}_{50}$ and $\mathrm{PIRIR}_{225}$ equivalent doses and their corresponding residual doses (after laboratory bleaching) with finite intercepts on the residual dose axes. They interpreted these intercepts as unbleachable residual doses that would have been present in their samples, had they been fully bleached at the time of deposition. Similar observations have been made by various workers for different pIRIR signals (e.g. Buylaert et al., 2012; Schatz et al., 2012; Sohbati et al., 2013; Tsukamoto et al., 2013; Veit et al., 2014; Qiu and Zhou, 2015). In the second method, we followed a similar approach; three aliquots per sample were first bleached for $4 \mathrm{~h}$ in a Hönle SOL2 solar simulator. The $\mathrm{IR}_{50}$ and pIRIR $_{225}$ residual doses were then measured and plotted against the corresponding $\mathrm{D}_{\mathrm{e}}$ values for each sample. As Fig. 7 shows there is a clear correlation between the residual doses and the equivalent doses. The intercepts of the linear fits to the $\mathrm{IR}_{50}$ and pIRIR $_{290}$ data are $1.6 \pm 0.3$ and $5.9 \pm 0.5 \mathrm{~Gy}$, respectively. Interestingly, these values are comparable to the residual doses observed in the youngest sample after $64 \mathrm{~h}$ of bleaching, and are similar to the values reported in literature for the same signals (e.g. Buylaert et al., 2012; Schatz et al., 2012; Murray et al., 2014; Kars et al., 2014b; Yi et al., 2015). It is not clear whether these residual doses originate from a truly unbleachable IRSL component or arise from the transfer of charge from light-insensitive traps to IR-sensitive trap(s) during preheating, so-called thermal transfer (e.g. Aitken, 1998; Buylaert et al., 2011). In either case, they would correspond to residual doses present in a fully bleached, modern sample and are likely to have been present in all our samples at the time of deposition. The resulting $I_{50}$ and pIRIR $_{290} \mathrm{D}_{\mathrm{e}}$ values after residual dose subtraction and the calculated pIRIR 290 ages are given in Table 1. 


\section{Discussion}

\subsection{Reliability of the luminescence ages: were the samples well-bleached?}

The laboratory behavior of the quartz OSL signals from these samples of New Zealand loess is satisfactory and the dose recovery for the sample tested under the chosen measurement conditions is consistent with unity $(0.98 \pm 0.06 ; \mathrm{n}=3)$. Thus for these samples it appears that our measurement protocol is appropriate for the measurement of dose. As discussed in the Introduction, this is in contrast to earlier work on quartz from South Island. With the exception of Holdaway et al. (2002) and Rowan et al. (2012) previous luminescence studies have concluded that quartz was insensitive and unsuitable for dating (e.g. Preusser et al., 2006; Almond et al., 2007).

Similarly, our feldspar IRSL dosimetry signal is also well-behaved. The slope of the measured to given dose relationship for the pIRIR $_{290}$ signal is within $10 \%$ of unity, and laboratory fading rates are not considered significant ( $\mathrm{g}_{2 \text { days }}$ values of $0.7 \pm 0.8$ and $0.9 \pm 0.3 \% /$ decade $(n=39)$ for the $\operatorname{IR}_{50}$ and $\mathrm{pIRIR}_{290}$ signals, respectively). Previous work suggested that ages based on feldspar IRSL signals underestimated independent age control (presumably due to anomalous fading) and this was blamed on the apparent high degree of weathering (Almond et al., 2001).

A major challenge in luminescence dating of hillslope deposits is incomplete bleaching (Fuchs and Lang, 2009). The colluvial deposits accumulated behind the boulders were reworked by slope processes and thus, because of short transport distances and mixing during transportation, may not have been well-bleached. Fuchs and Lang (2009) point out that one way to identify insufficient bleaching may be to use luminescence signals of different bleaching characteristics. Several studies have shown that the quartz OSL signal resets faster than the K-feldspar $\mathrm{IR}_{50}$ signal and that the $\mathrm{IR}_{50}$ signal, in turn, bleaches more rapidly than the elevated temperature post-IR IRSL (pIRIR) signals (e.g. Godfrey-Smith et al., 1988; Thomsen et al., 2008; Murray et al., 2012; Kars et al., 2014b; Sugisaki et al., 2015; Colarossi et al., 2015; Möller and Murray, 2015). Based on this, Murray et al. (2012) suggested an approach to identify well-bleached quartz samples by comparing quartz and K-feldspar equivalent doses. Möller and Murray (2015) used this approach in a study of Swedish glaciofluvial samples and were able to conclude that the quartz OSL in about half of the samples was well-bleached at deposition (based on agreement with $\mathrm{IR}_{50}$ and pIRIR signals). In our study, there is excellent agreement between 
the quartz OSL and K-feldspar pIRIR 290 ages for all the samples (Fig. 9). Given the well-known difference in bleaching rates (see above), this similarity in ages strongly suggests that the quartz OSL signals in our samples must have been well-bleached prior to final deposition (Fig. 9).

In addition, Buylaert et al. (2013) proposed an independent method to identify poorly-bleached Kfeldspar samples by comparing the $\mathrm{IR}_{50}$ to $\mathrm{pIRIR}_{290} \mathrm{D}_{\mathrm{e}}$ ratios. Following a similar approach, we plotted the $I_{50} D_{e}$ value versus the corresponding pIRIR 290 equivalent dose for each sample (Fig. 8). First of all, it is interesting to note that the value of intercept on the pIRIR 290 axis in Fig. 8 (i.e. 4.9 Gy), is indistinguishable from the difference between the values of $1.6 \pm 0.3$ and $5.9 \pm 0.5$ Gy inferred as $\mathrm{IR}_{50}$ and IRIR $_{290}$ unbleachable residual doses, respectively, from the intercepts on the $\mathrm{D}_{\mathrm{e}}$ axes in Fig. 7. Secondly, all data points lie on the same curve, indicating a good correlation of doses over a wide dose range (Fig. 8). Such smooth correlation implies that either all the samples were equally poorly-bleached or they were well-bleached. Given the heterogeneous nature of the bleaching process in space and time, the former seems unlikely. We conclude that these data suggest that both the feldspar signals from our samples were sufficiently bleached before deposition. Note that the poor dose recovery for the $\mathrm{IR}_{50}$ signals is most unlikely to perturb this conclusion. If poor dose recovery was to affect the conclusions drawn from this correlation, it would have to increase the scatter around the fitted line in Fig. 8; clearly, this cannot have happened to a significant degree. A similar conclusion was reached by Buylaert et al. (2013).

From the satisfactory dose recovery characteristics of the quartz OSL and K-feldspar pIRIR 290 signals and the excellent agreement between ages based on these signals, we conclude that the internal luminescence evidence strongly suggests that our quartz OSL ages are reliable and unlikely to have been significantly affected by incomplete bleaching. Since the quartz signal is more readily reset, and there are potential complications in the pIRIR $_{290}$ ages arising from signal instability and residual dose subtraction, we use the quartz OSL ages in the next section.

\subsection{OSL-CN age comparison}

The quartz OSL ages are all concordant with the stratigraphy; they range from $\sim 2$ to 29 ka with the 11 (out of 13) OSL ages most closely related to the boulders consistently younger than $\sim 13$ ka. Fig. 10 
shows a schematic view of one of the boulders (PB-2) together with the OSL ages of the surrounding loess colluvium deposits as well as the ${ }^{3} \mathrm{He}$ surface-exposure age from the top of the boulder. It can be seen that the two samples collected below the boundary identified as the ground surface at the time of boulder emplacement have ages of 12.5 $\pm 1.1 \mathrm{ka}$ (ROSL-05) and 12.0 $\pm 1.4 \mathrm{ka}$ (ROSL-06), the weighted average of which provides a maximum age limit of $12.3 \pm 1.0 \mathrm{ka}$ for the boulder deposition. Furthermore, sample ROSL-04, taken from the colluvial wedge upslope of the boulder and thus deposited after the boulder, has an age of $7.7 \pm 0.8 \mathrm{ka}$. These ages limit the boulder emplacement time to between $12.3 \pm 1.0 \mathrm{ka}$ and $7.7 \pm 0.8 \mathrm{ka}$. The maximum age limit of $12.3 \pm 1.0 \mathrm{ka}$ is indistinguishable from the ${ }^{3} \mathrm{He}$ exposure age of $13 \pm 2.3 \mathrm{ka}$ from the top surface of the boulder. Our preferred interpretation is that (i) PB-2 was emplaced at ca. 12-13 ka (Mackey and Quigley, 2014), (ii) ${ }^{3} \mathrm{He}$ pre-detachment inheritance is negligible, and (iii) the boulder emplacement time is indistinguishable from that of the underlying loess. In this instance, the possibility of significant ${ }^{3} \mathrm{He}$ inheritance is inconsistent with the optical chronology, highlighting the importance of these complementary data.

Maximum/minimum loess ages exist for only four of the boulders. Only one OSL sample (ROSL-02, $29 \pm 2 \mathrm{ka}$ ) was taken in association with PB1 (from underneath) and there is no corresponding upslope sample to provide post-depositional age limit. Fig. 11 summarizes the OSL age constraints and the ${ }^{3} \mathrm{He}$ surface-exposure age for the other four boulders (PB2, 3, 4, 5). The OSL ages associated with PB-3 suggest an emplacement time between $2.9 \pm 0.3$ and $5.8 \pm 0.5 \mathrm{ka}$, while the ${ }^{3} \mathrm{He}$ surface-exposure age from the top surface of the boulder is $8 \pm 2 \mathrm{ka}$. Again the boulder age is indistinguishable from that of the underlying loess, suggesting that either boulder emplacement occurred at $5.8 \pm 0.5 \mathrm{ka}$, or the boulder was emplaced after $5.8 \pm 0.5 \mathrm{ka}$ (and contained some ${ }^{3} \mathrm{He}$ inheritance) but before $2.9 \pm 0.3 \mathrm{ka}$.

In contrast, PB4 and PB5 have ${ }^{3}$ He surface-exposure ages that are significantly older than the ages of the associated loess. PB4 has an exposure age of $26.9 \pm 2.9 \mathrm{ka}$, while the OSL ages constrain the emplacement time to between $4.2 \pm 0.4$ and 10.2 $\pm 1.1 \mathrm{ka}$. Similarly, the OSL ages associated with PB5 suggest that it must have been deposited between $1.7 \pm 0.2$ and $10.2 \pm 0.8 \mathrm{ka}$, whereas the ${ }^{3} \mathrm{He}$ age suggests an emplacement time of $15.7 \pm 2.3 \mathrm{ka}$ (Fig. 11). Given the internal stratigraphic consistency of the quartz OSL ages and their agreement both with K-feldspar ages and with the regional climate record (i.e. loess formation during the termination of LGM), we conclude that the discrepancy between the OSL and ${ }^{3} \mathrm{He}$ ages for PB4 and PB5 is most likely due to pre-detachment ${ }^{3} \mathrm{He}$ inheritance. 


\section{Conclusions}

We successfully determined the emplacement time of palaeorockfall boulders by applying luminescence dating techniques to colluvial (reworked) loess deposits in South Island, New Zealand. The quartz OSL and K-feldspar pIRIR 290 ages are all consistent with stratigraphy and in excellent agreement with each other for all the samples. To our knowledge, these are amongst the first reliable loess luminescence ages from New Zealand, although a few earlier studies have reported reliable ages from non-loessic material (e.g. Holdaway et al., 2002; Rowan et al., 2012; Hornblow et al., 2014).

The correlation between the $\mathrm{IR}_{50}$ and $\mathrm{pIRIR}_{290} \mathrm{~K}$-feldspar equivalent doses and the corresponding residual doses seems to provide a reliable method to determine the unbleachable residual dose present in the samples. The size of the unbleachable $\operatorname{IR}_{50}$ and $\mathrm{pIRIR}_{290}$ residual doses in our samples, as inferred from the intercepts on the residual dose axes, are 1.6 \pm 0.3 and 5.9 $\pm 0.5 \mathrm{~Gy}$, respectively.

Regardless of whether the $\mathrm{IR}_{50}$ equivalent doses are reliable or not (due to poor dose recovery), the comparison between the $\mathrm{IR}_{50}$ and $\mathrm{pIRIR} \mathrm{D}_{\mathrm{e}}$ values appears to provide a viable independent approach to identify well-bleached K-feldspar samples. The smooth correlation between the $\mathrm{IR}_{50}$ and pIRIR $290 \mathrm{D}_{\mathrm{e}}$ values over a wide dose range, strongly suggests that all our samples were well-bleached prior to final deposition on the slope. This is confirmed by the agreement between the quartz OSL and K-feldspar pIRIR 290 ages.

Of the six loess colluvium samples immediately underlying the boulders the oldest has an age of $\sim 13$ ka, suggesting the deposition of loess colluvium after the termination of the LGM (Griffiths, 1973; Ives et al., 1973; Tonkin et al., 1974; Hughes et al., 2010). This implies that all the palaeorockfall boulders must have been emplaced after the loess colluvium deposition 13 ka ago (Mackey and Quigley, 2014). The emplacement time of individual boulders was further constrained by luminescence dating of colluvial (reworked) loess deposits underlying and upslope of individual boulders. A comparison of luminescence ages with ${ }^{3} \mathrm{He}$ surface-exposure ages from the surfaces of each boulder shows that two out of four boulders (ignoring PB1 because of the poor age constraint) probably suffer from ${ }^{3} \mathrm{He}$ predetachment inheritance, as hypothesized by Mackey and Quigley (2014). Overall, the optical ages are consistent with both a prehistoric rockfall event at $\sim 8-6 \mathrm{ka}$ and the possible preceding event at $\sim 14-13$ ka hypothesized by Mackey and Quigley (2014), although the temporal resolution of the time of 
emplacement of individual boulders remains at ca. 3-5 ka. However, this temporal resolution is not limited by age uncertainties but rather by the stratigraphy; there was simply no material deposited closer to the time of emplacement. Nevertheless, we are able to convincingly identify two boulders containing significant cosmogenic ${ }^{3} \mathrm{He}$ inheritance and two for which the ${ }^{3} \mathrm{He}$ ages are probably accurate, demonstrating the great advantage of a multi-technique approach in geochronology.

\section{Acknowledgements}

RS would like to thank Carlsberg Foundation for financial support (Grant no. 2012_01_0838) during this project. Joy Mailand-Hansen is thanked for sample preparation. The New Zealand Earthquake Commission is thanked for provision of finances under a Capability Grant and a Ph.D. scholarship to JB. Frontiers Abroad (http://frontiersabroad.com/) also provided financial support for this research. JPB thanks the Danish Council for Independent Research | Natural Sciences (FNU) for financial support (Steno grant no. 11-104566). 


\section{References}

Aitken, M. J. (1985). Thermoluminescence Dating. Academic Press, London

Aitken, M.J. (1998). An introduction to optical dating: the dating of Quaternary sediments by the use of photon-stimulated luminescence. Oxford University Press

Almond, P. C., Moar, N. T., \& Lian, O. B. (2001). Reinterpretation of the glacial chronology of South Westland, New Zealand. New Zealand Journal of Geology and Geophysics, 44(1), 1-15. doi:10.1080/00288306.2001.9514917

Almond, P. C., Shanhun, F. L., Rieser, U., \& Shulmeister, J. (2007). An OSL, radiocarbon and tephra isochron-based chronology for Birdlings Flat loess at Ahuriri Quarry, Banks Peninsula, Canterbury, New Zealand. Quaternary Geochronology, 2(1-4), 4-8. doi:10.1016/j.quageo.2006.06.002

André, M. (1997). Holocene Rockwall Retreat in Svalbard: A Triple-Rate Evolution. Earth Surface Processes and Landforms, 22(5), 423-440. doi:10.1002/(SICI)10969837(199705)22:5<423::AID-ESP706>3.3.CO;2-Y

Auclair, M., Lamothe, M., \& Huot, S. (2003). Measurement of anomalous fading for feldspar IRSL using SAR. Radiation Measurements, 37(4-5), 487-492. doi:10.1016/S1350-4487(03)00018-0

Baillifard, F., Jaboyedoff, M., \& Sartori, M. (2003). Rockfall hazard mapping along a mountainous road in Switzerland using a GIS-based parameter rating approach. Natural Hazards and Earth System Science, 3(5), 435-442. doi:10.5194/nhess-3-435-2003

Balescu, S., Ritz, J. F., Lamothe, M., Auclair, M., \& Todbileg, M. (2007). Luminescence dating of a gigantic palaeolandslide in the Gobi-Altay mountains, Mongolia. Quaternary Geochronology, 2(1-4), 290-295. doi:10.1016/j.quageo.2006.05.026 
Berger, G. W., Almond, P. C., \& Pillans, B. J. (2001a). Luminescence dating and glacial stratigraphy in Westland, New Zealand. New Zealand Journal of Geology and Geophysics, 44(1), 25-35. doi:10.1080/00288306.2001.9514919

Berger, G. W., Pillans, B. J., \& Tonkin, P. J. (2001b). Luminescence chronology of loess-palaeosol sequences from Canterbury, South Island, New Zealand. New Zealand Journal of Geology and Geophysics, 44(4), 501-516. doi:10.1080/00288306.2001.9514952

Berger, G. W., Pillans, B. J., Bruce, J. G., \& McIntosh, P. D. (2002). Luminescence chronology of loess-palaeosol sequences from southern South Island, New Zealand. Quaternary Science Reviews, 21(16-17), 1899-1913. doi:10.1016/S0277-3791(02)00021-5

Bertolini, G. (2007). Radiocarbon dating on landslides in the Northern Apennines (Italy) (pp. 73-80). doi:10.1201/NOE0415443180.ch10

Borella, J., Quigley, M., Vick, L. (in review). Anthropocene rockfalls exceed limits of prehistoric predecessors. Nature Geoscience.

Borella, J., Quigley, M., Sohbati, R., Kuklewicz, K. (in review), Stratigraphy and chronology of late Quaternary loessic hillslope sediments reveals seismic, climatic, and anthropogenic influence on surface processes, eastern South Island, New Zealand

Budetta, P. (2004). Assessment of rockfall risk along roads. Natural Hazards and Earth System Science, 4(1), 71-81. doi:10.5194/nhess-4-71-2004

Bull, W. B., King, J., Kong, F., Moutoux, T., \& Phillips, W. M. (1994). Lichen dating of coseismic landslide hazards in alpine mountains. Geomorphology, 10(1-4), 253-264. doi:10.1016/0169$555 \mathrm{X}(94) 90020-5$

Bull, W. B. (1996). Dating San Andreas fault earthquakes with lichenometry. Geology, 24(2), 111. doi:10.1130/0091-7613 
Bunce, C. M., Cruden, D. M., \& Morgenstern, N. R. (1998). Assessment of the hazard from rock fall on a highway. Canadian Geotechnical Journal, 35(2), 410. doi:10.1139/t98-002

Buylaert, J. P., Murray, A. S., Thomsen, K. J., \& Jain, M. (2009). Testing the potential of an elevated temperature IRSL signal from K-feldspar. Radiation Measurements, 44(5-6), 554-559. doi:10.1016/j.radmeas.2009.02.004

Buylaert, J.-P., Thiel, C., Murray, A. S., Vandenberghe, D. A. G., Yi, S., \& Lu, H. (2011). IRSL and post-IR IRSL residual doses recorded in modern dust samples from the Chinese Loess Plateau. Geochronometria, 38(4), 432-440. doi:10.2478/s13386-011-0047-0

Buylaert, J.-P., Jain, M., Murray, A. S., Thomsen, K. J., Thiel, C., \& Sohbati, R. (2012). A robust feldspar luminescence dating method for Middle and Late Pleistocene sediments. Boreas, 41, 435-451. doi:10.1111/j.1502-3885.2012.00248.x

Buylaert, J.-P., Murray, a. S., Gebhardt, A. C., Sohbati, R., Ohlendorf, C., Thiel, C., ... Zolitschka, B. (2013). Luminescence dating of the PASADO core 5022-1D from Laguna Potrok Aike (Argentina) using IRSL signals from feldspar. Quaternary Science Reviews, 71, 70-80. doi:10.1016/j.quascirev.2013.03.018

Chapot, M. S., Sohbati, R., Murray, A. S., Pederson, J. L., \& Rittenour, T. M. (2012). Constraining the age of rock art by dating a rockfall event using sediment and rock-surface luminescence dating techniques. Quaternary Geochronology, 13, 18-25. doi:10.1016/j.quageo.2012.08.005

Colarossi, D., Duller, G. a. T., Roberts, H. M., Tooth, S., \& Lyons, R. (2015). Comparison of paired quartz OSL and feldspar post-IR IRSL dose distributions in poorly bleached fluvial sediments from South Africa. Quaternary Geochronology, 1-6. doi:10.1016/j.quageo.2015.02.015

Cunningham, A. C., \& Wallinga, J. (2010). Selection of integration time intervals for quartz OSL decay curves. Quaternary Geochronology, 5(6), 657-666. doi:10.1016/j.quageo.2010.08.004 
Dilley, M., Chen, R. S., Deichmann, U., Lerner-Lam, A. L., Arnold, M., Agwe, J., ... Yetman, G. (2005). Natural Disaster Hotspots A Global Risk Analysis. Earth Science.

Evans, S. G., \& Hungr, O. (1993). The assessment of rockfall hazard at the base of talus slopes. Canadian Geotechnical Journal. doi:10.1139/t93-054

Fuchs, M., \& Lang, A. (2009). Luminescence dating of hillslope deposits-A review. Geomorphology, 109(1-2), 17-26. doi:10.1016/j.geomorph.2008.08.025

Godfrey-Smith, D., Huntley, D., \& Chen, W. (1988). Optical dating studies of quartz and feldspar sediment extracts. Quaternary Science Reviews, 7, 373-380.

Guzzetti, F. (2000). Landslide fatalities and the evaluation of landslide risk in Italy. Engineering Geology, 58(2), 89-107. doi:10.1016/S0013-7952(00)00047-8

Guérin, G., Mercier, N., \& Adamiec, G. (2011). Dose-rate conversion factors : update, 29(1), 5-8.

Heron, D., Lukovic, B., Massey, C., Ries, W., \& McSaveney, M. (2014). GIS modelling in support of earthquake-induced rockfall and cliff collapse risk assessment in the Port Hills, Christchurch. Journal of Spatial Science, 59(2), 313-332.

Holdaway, R. N., Roberts, R. G., Beavan-Athfield, N. R., Olley, J. M., \& Worthy, T. H. (2002). C dating of bone gelatin and moa eggshell: A comparison of age estimates for non-archaeological deposits in New Zealand. Journal of the Royal Society of New Zealand, 32(3), 463-505. doi:10.1080/03014223.2002.9517705

Hornblow, S., Quigley, M., Nicol, A., Van Dissen, R., Wang, N. (2014) Paleoseismology of the 2010 Mw 7.1 Darfield (Canterbury) earthquake source, Greendale Fault, New Zealand, Tectonophysics, $637,178-190$

Hughes, M. W., Almond, P. C., Roering, J. J., \& Tonkin, P. J. (2010). Late Quaternary loess landscape evolution on an active tectonic margin, Charwell Basin, South Island, New Zealand. Geomorphology, 122(3-4), 294-308. doi:10.1016/j.geomorph.2009.09.034 
Hungr, O., Evans, S. G., \& Hazzard, J. (1999). Magnitude and frequency of rock falls and rock slides along the main transportation corridors of southwestern British Columbia. Canadian Geotechnical Journal. doi:10.1139/t98-106

Huntley, D., \& Baril, M. (1997). The K content of the K-feldspars being measured in optical dating or in thermoluminescence dating. Ancient TL, (1), 11-13.

Huntley, D. J. \& Hancock, R. G. V. (2001). The Rb contents of the K-feldspar grains being measured in optical dating. Ancient TL, 19, 43-46.

Huntley, D. J., \& Lamothe, M. (2001). Ubiquity of anomalous fading in K-feldspars and the measurement and correction for it in optical dating. Canadian Journal of Earth Sciences, 38(7), 1093-1106. doi:10.1139/cjes-38-7-1093

Ives, D. (1973). Nature and distribution of loess in Canterbury, New Zealand. New Zealand journal of geology and geophysics, 16(3), 587-610.

Jain, M., Murray, A. S., \& Bøtter-Jensen, L. (2003). Characterisation of blue-light stimulated luminescence components in different quartz samples: implications for dose measurement. Radiation Measurements, 37(4-5), 441-449. doi:10.1016/S1350-4487(03)00052-0

Jain, M., Sohbati, R., Guralnik, B., Murray, A. S., Kook, M., Lapp, T., ... Buylaert, J. P. (2015). Kinetics of infrared stimulated luminescence from feldspars. Radiation Measurements. doi:10.1016/j.radmeas.2015.02.006

Kars, R. H., Reimann, T., \& Wallinga, J. (2014a). Are feldspar SAR protocols appropriate for post-IR IRSL dating? Quaternary Geochronology, 22, 126-136. doi:10.1016/j.quageo.2014.04.001

Kars, R. H., Reimann, T., Ankjaergaard, C., \& Wallinga, J. (2014b). Bleaching of the post-IR IRSL signal: new insights for feldspar luminescence dating. Boreas, 43(4), 780-791. doi:10.1111/bor.12082 
Keefer, D. K. (1984). Landslides caused by earthquakes. Geological Society of America Bulletin, 95(4), 406-421. doi:10.1130/0016-7606(1984)95<406:LCBE $>2.0 . C O$

Lang, A., Moya, J., Corominas, J., Schrott, L., \& Dikau, R. (1999). Classic and new dating methods for assessing the temporal occurrence of mass movements. Geomorphology, 30(1-2), 33-52. doi:10.1016/S0169-555X(99)00043-4

Li, B., \& Li, S.-H. (2006). Comparison of estimates using the fast component and the medium component of quartz OSL. Radiation Measurements, 41(2), 125-136. doi:10.1016/j.radmeas.2005.06.037

Li, B., Roberts, R. G., \& Jacobs, Z. (2013). On the dose dependency of the bleachable and nonbleachable components of IRSL from K-feldspar: Improved procedures for luminescence dating of Quaternary sediments. Quaternary Geochronology, 17, 1-13. doi:10.1016/j.quageo.2013.03.006

Li, G., Wen, L., Xia, D., Duan, Y., Rao, Z., Madsen, D. B., ... Chen, F. (2015). Quartz OSL and Kfeldspar pIRIR dating of a loess/palaeosol sequence from arid central Asia, Tianshan Mountains, NW China. Quaternary Geochronology, 28, 40-53. doi:10.1016/j.quageo.2015.03.011

Litchfield, N. J., \& Lian, O. B. (2004). Luminescence age estimates of Pleistocene marine terrace and alluvial fan sediments associated with tectonic activity along coastal Otago, New Zealand. New Zealand Journal of Geology and Geophysics, 47(1), 29-37. doi:10.1080/00288306.2004.9515035

Lowick, S. E., Trauerstein, M., \& Preusser, F. (2012). Testing the application of post IR-IRSL dating to fine grain waterlain sediments. Quaternary Geochronology, 8(1), 33-40. doi:10.1016/j.quageo.2011.12.003

Luckman B. H., \& Fiske, C. J. (1995). Estimating long-term rockfall accretion rates by lichenometry. In Steepland Geomorphology, Slaymaker O (ed.). Wiley: Chichester; 233-255. 
Mackey, B. H., \& Quigley, M. C. (2014). Strong proximal earthquakes revealed by cosmogenic 3He dating of prehistoric rockfalls, Christchurch, New Zealand. Geology, 42(11), 975-978. doi:10.1130/G36149.1

Massey, Chris I., Mauri J. McSaveney, Tony Taig, Laurie Richards, Nicola J. Litchfield, David A. Rhoades, Graeme H. McVerry et al. "Determining rockfall risk in Christchurch using rockfalls triggered by the 2010-2011 Canterbury earthquake sequence." Earthquake Spectra 30, no. 1 (2014): 155-181.

Matmon, A, Shaked, Y., Porat, N., Enzel, Y., Finkel, R., Lifton, N., ... Agnon, A. (2005). Landscape development in an hyperarid sandstone environment along the margins of the Dead Sea fault: Implications from dated rock falls. Earth and Planetary Science Letters, 240(3-4), 803-817. doi:10.1016/j.eps1.2005.06.059

McCarroll, D., Shakesby, R. a., \& Matthews, J. A. (2001). Enhanced rockfall activity during the litte ice age: Further lichenometric evidence from a Norwegian Talus. Permafrost and Periglacial Processes, 12(2), 157-164. doi:10.1002/ppp.359

Mejdahl, V. (1987). Internal radioactivity in quartz and feldspar grains. Ancient TL.

Murray, A. S., \& Wintle, A. G. (2000). Luminescence dating of quartz using an improved singlealiquot regenerative-dose protocol. Radiation Measurements, 32, 3-7.

Murray, A. S., \& Wintle, A. G. (2003). The single aliquot regenerative dose protocol: potential for improvements in reliability. Radiation Measurements, 37(4-5), 377-381. doi:10.1016/S13504487(03)00053-2

Murray, A. S., Thomsen, K. J., Masuda, N., Buylaert, J. P., \& Jain, M. (2012). Identifying wellbleached quartz using the different bleaching rates of quartz and feldspar luminescence signals. Radiation Measurements, 47(9), 688-695. doi:10.1016/j.radmeas.2012.05.006 
Murray, A. S., Schmidt, E. D., Stevens, T., Buylaert, J. P., Marković, S. B., Tsukamoto, S., \& Frechen, M. (2014). Dating middle pleistocene loess from stari slankamen (vojvodina, serbia) - limitations imposed by the saturation behaviour of an elevated temperature IRSL signal. Catena, 117, 34-42. doi:10.1016/j.catena.2013.06.029

Möller, P., \& Murray, A. S. (2015). Drumlinised glaciofluvial and glaciolacustrine sediments on the Småland peneplain, South Sweden - new information on the growth and decay history of the Fennoscandian Ice Sheets during MIS 3. Quaternary Science Reviews, 122, 1-29. doi:10.1016/j.quascirev.2015.04.025

Nesje, A., Blikra, L. H., \& Anda, E. (1994). Dating rockfall-avalanche deposits from degree of rocksurface weathering by Schmidt-hammer tests: a study from Norangsdalen, Sunnmøre, Norway.

Panek, T. (2014). Recent progress in landslide dating: A global overview. Progress in Physical Geography, 39(2), 168-198. doi:10.1177/0309133314550671

Preusser, F., Andersen, B. G., Denton, G. H., \& Schlüchter, C. (2005). Luminescence chronology of Late Pleistocene glacial deposits in North Westland, New Zealand. Quaternary Science Reviews, 24(20-21), 2207-2227. doi:10.1016/j.quascirev.2004.12.005

Preusser, F., Ramseyer, K., \& Schlüchter, C. (2006). Characterisation of low OSL intensity quartz from the New Zealand Alps. Radiation Measurements, 41(7-8), 871-877. doi:10.1016/j.radmeas.2006.04.019

Reimann, T., \& Tsukamoto, S. (2012). Dating the recent past ( $<500$ years) by post-IR IRSL feldspar Examples from the North Sea and Baltic Sea coast. Quaternary Geochronology, 10, 180-187. doi:10.1016/j.quageo.2012.04.011

Rinat, Y., Matmon, A., Arnold, M., Aumaître, G., Bourlès, D., Keddadouche, K., ... Finkel, R. C. (2014). Holocene rockfalls in the southern Negev Desert, Israel and their relation to Dead Sea fault earthquakes. Quaternary Research, 81(2), 260-273. doi:10.1016/j.yqres.2013.12.008 
Roberts, H. M. (2012). Testing Post-IR IRSL protocols for minimising fading in feldspars, using Alaskan loess with independent chronological control. Radiation Measurements, 47(9), 716-724. doi:10.1016/j.radmeas.2012.03.022

Roskosch, J., Tsukamoto, S., Meinsen, J., Frechen, M., \& Winsemann, J. (2012). Luminescence dating of an Upper Pleistocene alluvial fan and aeolian sandsheet complex: The Senne in the M??nsterland Embayment, NW Germany. Quaternary Geochronology, 10, 94-101. doi:10.1016/j.quageo.2012.02.012

Schatz, A. K., Buylaert, J. P., Murray, A., Stevens, T., \& Scholten, T. (2012). Establishing a luminescence chronology for a palaeosol-loess profile at Tokaj (Hungary): A comparison of quartz OSL and polymineral IRSL signals. Quaternary Geochronology, 10, 68-74. doi:10.1016/j.quageo.2012.02.018

Sohbati, R., Murray, A. S., Buylaert, J.-P., Ortuño, M., Cunha, P. P., \& Masana, E. (2012). Luminescence dating of Pleistocene alluvial sediments affected by the Alhama de Murcia fault (eastern Betics, Spain) - a comparison between OSL, IRSL and post-IRIRSL ages. Boreas, 41(2), 250-262. doi:10.1111/j.1502-3885.2011.00230.x

Sohbati, R., Murray, A., Jain, M., Thomsen, K., Hong, S.-C., Yi, K., \& Choi, J.-H. (2013). Na-rich feldspar as a luminescence dosimeter in infrared stimulated luminescence (IRSL) dating. Radiation Measurements, 51-52, 67-82. doi:10.1016/j.radmeas.2012.12.011

Spooner, N. A. (1994). The anomalous fading of infrared-stimulated luminescence from feldspars. Radiation Measurements. doi:10.1016/1350-4487(94)90111-2

Stevens, T., Marković, S. B., Zech, M., Hambach, U., \& Sümegi, P. (2011). Dust deposition and climate in the Carpathian Basin over an independently dated last glacial-interglacial cycle. Quaternary Science Reviews, 30(5-6), 662-681. doi:10.1016/j.quascirev.2010.12.011

Stock, G. M., \& Collins, B. D. (2014). Reducing Rockfall Risk in Yosemite National Park. Eos, Transactions American Geophysical Union, 95(29), 261-263. doi:10.1002/2014EO290002 
Stoffel, M. (2006). A Review of Studies Dealing with Tree Rings and Rockfall Activity: The Role of Dendrogeomorphology in Natural Hazard Research. Natural Hazards, 39(1), 51-70. doi:10.1007/s1 1069-005-2961-z

Stout, M., L. (1969). Radiocarbon Dating of Landslides in Southern California and Engineering Geology Implications. Geological Society of America Special Papers, 123, 167-180, doi: 10.1130/SPE123-p167

Sugisaki, S., Buylaert, J.-P., Murray, A., Tada, R., Zheng Hongbo, Ke, W., ... Irino, T. (2015). OSL dating of fine-grained quartz from Holocene Yangtze delta sediments. Quaternary Geochronology, 1-7. doi:10.1016/j.quageo.2015.02.021

Talebian, M., Fielding, E. J., Funning, G. J., Ghorashi, M., Jackson, J., Nazari, H., ... Wright, T. J. (2004). The 2003 Bam (Iran) earthquake: Rupture of a blind strike-slip fault. Geophysical Research Letters, 31(11), 2-5. doi:10.1029/2004GL020058

Thiel, C., Buylaert, J.-P., Murray, A., Terhorst, B., Hofer, I., Tsukamoto, S., \& Frechen, M. (2011). Luminescence dating of the Stratzing loess profile (Austria) - Testing the potential of an elevated temperature post-IR IRSL protocol. Quaternary International, 234(1-2), 23-31. doi:10.1016/j.quaint.2010.05.018

Thomsen, K., Murray, a, Jain, M., \& Botterjensen, L. (2008). Laboratory fading rates of various luminescence signals from feldspar-rich sediment extracts. Radiation Measurements, 43(9-10), 1474-1486. doi:10.1016/j.radmeas.2008.06.002

Tonkin, P. J., Runge, E. C. A., \& Ives, D. W. (1974). A study of Late Pleistocene loess deposits, South Canterbury, New Zealand: Part II. Palaeosols and their stratigraphic implications. Quaternary research, 4(2), 217-231.

Tsukamoto, S., Kataoka, K. S., \& Miyabuchi, Y. (2013). Luminescence dating of volcanogenic outburst flood sediments from Aso volcano and tephric loess deposits, southwest Japan. Geochronometria, 40(4), 294-303. doi:10.2478/s13386-013-0135-4 
Vandenberghe, D., De Corte, F., Buylaert, J.-P., Kučera, J., \& Van den haute, P. (2008). On the internal radioactivity in quartz. Radiation Measurements, 43(2-6), 771-775. doi:10.1016/j.radmeas.2008.01.016

Veit, H., Preusser, F., \& Trauerstein, M. (2014). The Southern Westerlies in Central Chile during the two last glacial cycles as documented by coastal aeolian sand deposits and intercalating palaeosols. Catena, 134, 30-40. doi:10.1016/j.catena.2014.11.002

Yi, S., Buylaert, J.-P., Murray, A. S., Thiel, C., Zeng, L., \& Lu, H. (2015). High resolution OSL and post-IR IRSL dating of the last interglacial-glacial cycle at the Sanbahuo loess site (northeastern China). Quaternary Geochronology, 1-7. doi:10.1016/j.quageo.2015.02.013

Yin, Y., Wang, F., \& Sun, P. (2009). Landslide hazards triggered by the 2008 Wenchuan earthquake, Sichuan, China. Landslides, 6(2), 139-152. doi:10.1007/s10346-009-0148-5

Wallinga, J., Murray, A., \& Duller, G. (2000). Underestimation of equivalent dose in single-aliquot optical dating of feldspars caused by preheating. Radiation Measurements, 32(5-6), 691-695. doi:10.1016/S1350-4487(00)00127-X

Wallinga, J., Bos, A. J. J., Dorenbos, P., Murray, A. S., \& Schokker, J. (2007). A test case for anomalous fading correction in IRSL dating. Quaternary Geochronology, 2(1-4), 216-221. doi:10.1016/j.quageo.2006.05.014

Wintle, A. G. (1973). Anomalous Fading of Thermo-luminescence in Mineral Samples. Nature, 245(5421), 143-144. doi:10.1038/245143a0 


\section{Table captions}

Table 1) Summary of sample code, burial depth, radionuclide concentrations, measured water content, quartz OSL and K-feldspar IR $_{50}$ and pIRIR $_{290}$ equivalent doses and ages. Residual doses of 1.2 and 6 Gy were subtracted from the $I_{50}$ and $\operatorname{pIRIR}_{290} \mathrm{D}_{\mathrm{e}} \mathrm{s}$, respectively. Feldspar dose rates assume a $\mathrm{K}$ concentration of $12.5 \pm 0.5 \%$ for K-feldspar (Huntley and Baril, 1997). An absolute error of $4 \%$ is assumed on the water content values.

Table 2) Outline of the quartz OSL (Murray and Wintle, 2003) and K-feldspar pIRIR 290 (Thiel et al., 2011) SAR protocols. 


\begin{tabular}{|c|c|c|c|c|c|c|c|c|c|c|c|c|c|c|}
\hline $\begin{array}{l}\text { Sample } \\
\text { code }\end{array}$ & $\begin{array}{c}\text { Sample } \\
\text { name }\end{array}$ & Depth & $\begin{array}{l}\text { Water } \\
\text { content }\end{array}$ & ${ }^{226} \mathrm{Ra}$ & ${ }^{232} \mathrm{Th}$ & ${ }^{40} \mathrm{~K}$ & $\begin{array}{c}\text { Total } \\
\text { dose rate }\end{array}$ & $\begin{array}{l}\text { Quartz } \\
\text { OSL De }\end{array}$ & $\mathrm{n}$ & $\begin{array}{l}\text { Quartz } \\
\text { OSL age }\end{array}$ & $\begin{array}{c}\text { K-feldspar } \\
\operatorname{IR}_{50} D_{\mathrm{e}}\end{array}$ & $\begin{array}{l}\text { K-feldspar } \\
\text { pIRIR }_{290} D_{\mathrm{e}}\end{array}$ & $\mathrm{n}$ & $\begin{array}{c}\text { K-feldspar } \\
\text { pIRIR }_{290} \text { age }\end{array}$ \\
\hline & & & $(\%)$ & $\left(\mathrm{Bq} \mathrm{kg}^{-1}\right)$ & $\left(\mathrm{Bq} \mathrm{kg}^{-1}\right)$ & $(\mathrm{Bq} \mathrm{kg}$ & $\left(\mathrm{Gy} \mathrm{ka}^{-1}\right)$ & (Gy) & & (ka) & (Gy) & (Gy) & & (ka) \\
\hline & & (cr & & $\pm \mathrm{se}$ & $\pm \mathrm{se}$ & $\pm \mathrm{se}$ & $\pm \mathrm{se}$ & $\pm \mathrm{se}$ & & $\pm \mathrm{se}$ & $\pm \mathrm{se}$ & $\pm \mathrm{se}$ & & $\pm \mathrm{se}$ \\
\hline 146601 & ROSL-02 (PB1) & 247 & 10 & $30.14 \pm 1.08$ & $40.07 \pm 1.16$ & $502 \pm 16$ & $2.65 \pm 0.13$ & $78 \pm 5$ & 17 & $29.3 \pm 2.5$ & $44.24 \pm 1.14$ & $84.3 \pm 1.8$ & 12 & $28.5 \pm 1.6$ \\
\hline 146602 & ROSL-08 (PB3) & 81 & 14 & $35.8 \pm 0.9$ & $42.3 \pm 0.9$ & $554 \pm 16$ & $2.85 \pm 0.12$ & $8.14 \pm 0.66$ & 18 & $2.9 \pm 0.3$ & $4.07 \pm 0.30$ & $8.4 \pm 0.4$ & 12 & $2.6 \pm 0.2$ \\
\hline 146603 & ROSL-09 (PB3) & 170 & 6 & $33.38 \pm 1.14$ & $38.5 \pm 1.2$ & $446 \pm 16$ & $2.76 \pm 0.14$ & $15.9 \pm 1.2$ & 18 & $5.8 \pm 0.5$ & $11.8 \pm 0.6$ & $19.9 \pm 0.6$ & 12 & $6.5 \pm 0.4$ \\
\hline 146604 & ROSL-10 (PB4) & 93 & 11 & $32.7 \pm 0.9$ & $41 \pm 1$ & $473 \pm 12$ & $2.66 \pm 0.12$ & $11.0 \pm 0.9$ & 18 & $4.2 \pm 0.4$ & $7.4 \pm 0.5$ & $11.4 \pm 0.5$ & 12 & $3.8 \pm 0.2$ \\
\hline 146605 & ROSL-11 (PB4) & 120 & 8 & $38.6 \pm 1.9$ & $42 \pm 2$ & $440 \pm 30$ & $2.55 \pm 0.15$ & $26 \pm 2$ & 18 & $10.25 \pm 1.07$ & $16.5 \pm 0.5$ & $29.8 \pm 1.0$ & 12 & $10.4 \pm 0.7$ \\
\hline 146606 & ROSL-12 (PB4) & 131 & 7 & $33.8 \pm 1.6$ & $42.5 \pm 1.7$ & $510 \pm 20$ & $2.87 \pm 0.16$ & $38 \pm 3$ & 18 & $13.4 \pm 1.2$ & $23.7 \pm 0.6$ & $40.4 \pm 0.6$ & 12 & $12.7 \pm 0.7$ \\
\hline 146607 & ROSL-13 (PB5) & 31 & 4 & $36.2 \pm 1.7$ & $42.8 \pm 1.8$ & $520 \pm 20$ & $3.18 \pm 0.17$ & $5.5 \pm 0.4$ & 22 & $1.7 \pm 0.2$ & $3.8 \pm 0.3$ & $6.8 \pm 0.3$ & 12 & $1.94 \pm 0.14$ \\
\hline 146608 & ROSL-14 (PB5) & 110 & 8 & $35.9 \pm 1.7$ & $43.5 \pm 1.9$ & $460 \pm 30$ & $2.94 \pm 0.16$ & $30.0 \pm 1.7$ & 24 & $10.2 \pm 0.8$ & $22.7 \pm 0.7$ & $40.7 \pm 0.9$ & 12 & $12.6 \pm 0.8$ \\
\hline 146609 & ROSL-03 (PB2) & 70 & 12 & $32.6 \pm 1.2$ & $39.877 \pm 1.114$ & $470 \pm 20$ & $2.69 \pm 0.13$ & $7.6 \pm 0.7$ & 24 & $2.8 \pm 0.3$ & $4.5 \pm 0.3$ & $7.4 \pm 0.3$ & 12 & $2.46 \pm 0.15$ \\
\hline 146610 & ROSL-06 (PB2) & 87 & 7 & $31.9 \pm 1.5$ & $43.2 \pm 1.4$ & $490 \pm 30$ & $2.89 \pm 0.15$ & $35 \pm 4$ & 24 & $12.0 \pm 1.4$ & $18.5 \pm 0.4$ & $32.7 \pm 0.7$ & 12 & $10.2 \pm 0.6$ \\
\hline 146611 & ROSL-07 (PB2) & 171 & 4 & $31.5 \pm 1.6$ & $49 \pm 1.8$ & $440 \pm 20$ & $2.93 \pm 0.16$ & $80 \pm 8$ & 22 & $27.2 \pm 3.0$ & $39.2 \pm 1.4$ & $70.5 \pm 1.9$ & 12 & $21.8 \pm 1.4$ \\
\hline 146612 & ROSL-04 (PB2) & 99 & 12 & $35.8 \pm 1.5$ & $40.3 \pm 1.4$ & $460 \pm 20$ & $2.47 \pm 0.13$ & $19.0 \pm 1.5$ & 23 & $7.7 \pm 0.8$ & $11.13 \pm 0.35$ & $19.2 \pm 0.3$ & 12 & $6.9 \pm 0.4$ \\
\hline 146613 & ROSL-05 (PB2) & 116 & 9 & $34.6 \pm 1.6$ & $40.4 \pm 1.7$ & $480 \pm 20$ & $2.79 \pm 0.15$ & $35 \pm 2$ & 17 & $12.47 \pm 1.06$ & $19.0 \pm 0.3$ & $33.7 \pm 0.4$ & 12 & $10.8 \pm 0.6$ \\
\hline
\end{tabular}

\section{Table 1}




\begin{tabular}{lllll}
\hline Step & Quartz & K-feldspar & Observed \\
\hline & Treatment & Observed & Treatment & \\
\hline 1 & Dose & & Dose & \\
2 & Preheat $\left(260^{\circ} \mathrm{C}\right.$ for $\left.10 \mathrm{~s}\right)$ & Preheat $\left(320^{\circ} \mathrm{C}\right.$ for $\left.60 \mathrm{~s}\right)$ & \\
3 & Blue stimulation $\left(125^{\circ} \mathrm{C}\right.$ for $\left.40 \mathrm{~s}\right)$ & $\mathrm{L}_{\mathrm{x}}$ & Infrared stimulation $\left(50^{\circ} \mathrm{C}\right.$ for $\left.100 \mathrm{~s}\right)$ & $\mathrm{L}_{\mathrm{x}, \text { IR50 }}$ \\
4 & ------ & Infrared stimulation $\left(290^{\circ} \mathrm{C}\right.$ for $\left.100 \mathrm{~s}\right)$ & $\mathrm{L}_{\mathrm{x}, \text { pIRIR290 }}$ \\
5 & Test dose & & Test dose & \\
6 & Cut heat $\left(240^{\circ} \mathrm{C}\right)$ & Preheat $\left(320^{\circ} \mathrm{C}\right.$ for $\left.60 \mathrm{~s}\right)$ & $\mathrm{T}_{\mathrm{x}, \text { IR50 }}$ \\
7 & Blue stimulation $\left(125^{\circ} \mathrm{C}\right.$ for $\left.40 \mathrm{~s}\right)$ & $\mathrm{T}_{\mathrm{x}}$ & Infrared stimulation $\left(50^{\circ} \mathrm{C}\right.$ for $\left.100 \mathrm{~s}\right)$ & $\mathrm{T}_{\mathrm{x}, \text { pIRIR290 }}$ \\
8 & ----- & & Infrared stimulation $\left(290^{\circ} \mathrm{C}\right.$ for $\left.100 \mathrm{~s}\right)$ & \\
9 & Blue stimulation $\left(280^{\circ} \mathrm{C}\right.$ for $\left.40 \mathrm{~s}\right)$ & & Infrared stimulation $\left(325^{\circ} \mathrm{C}\right.$ for $\left.100 \mathrm{~s}\right)$ & \\
10 & Return to 1 & & Return to 1 & \\
\hline
\end{tabular}

\section{Table 2}




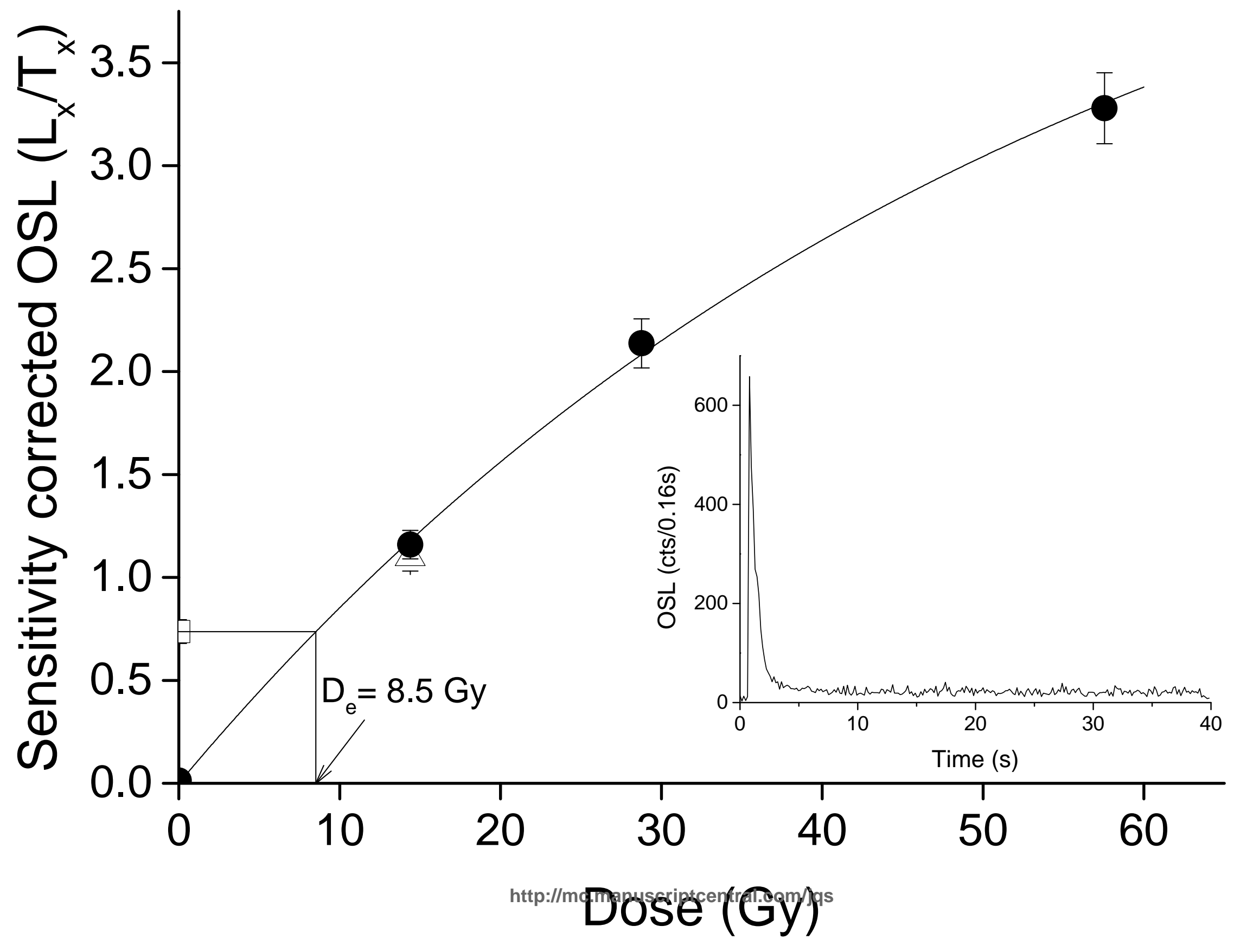




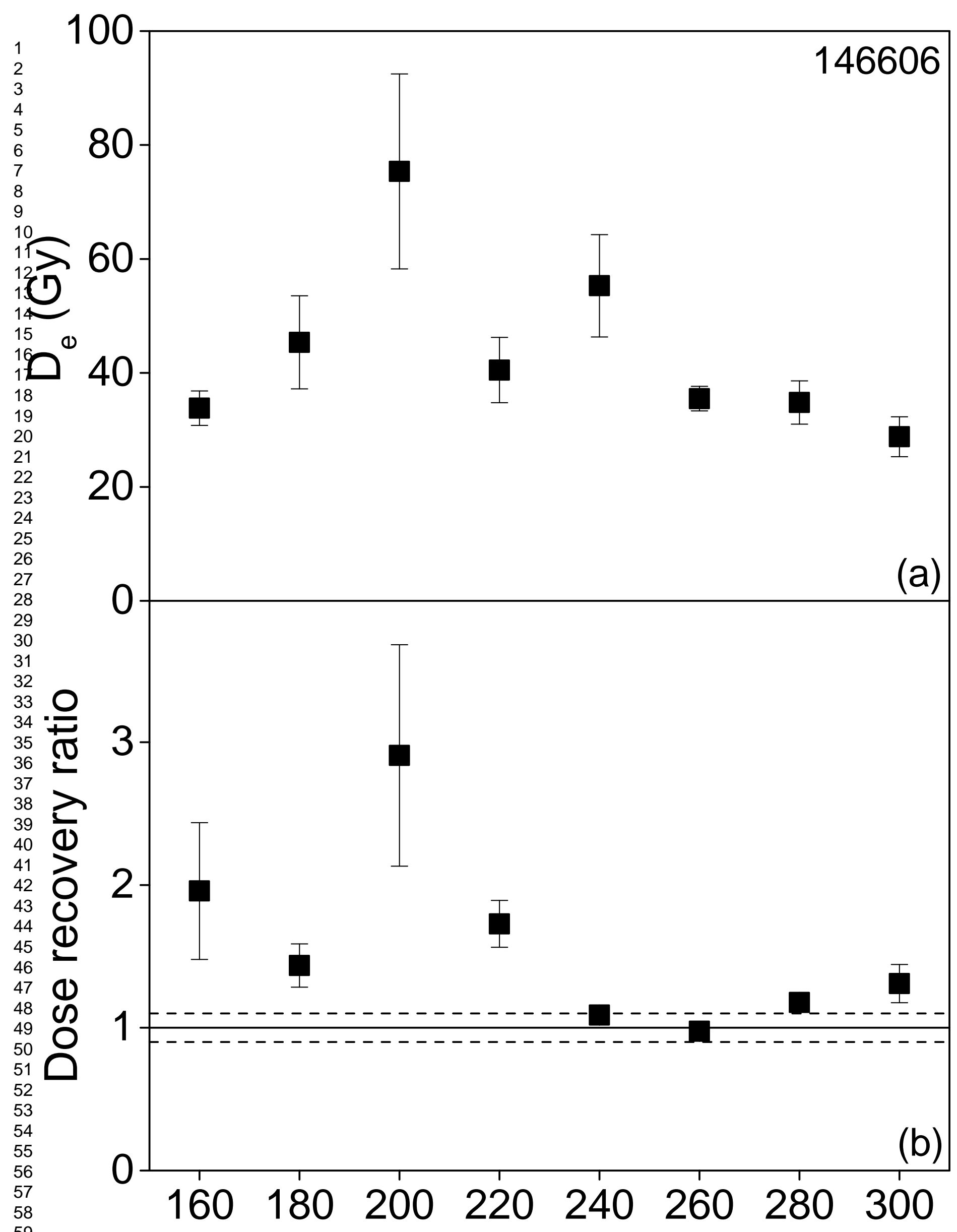




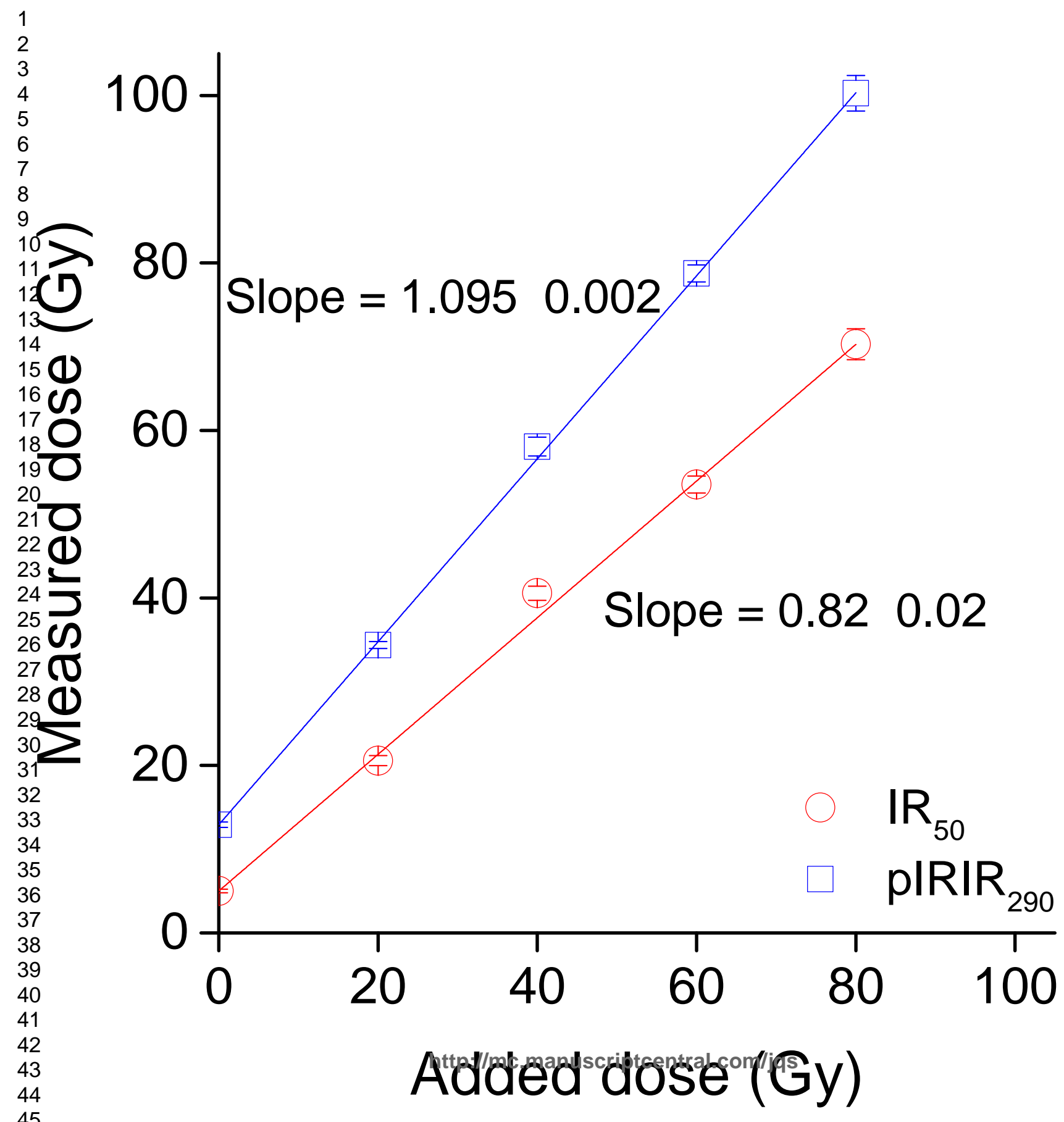




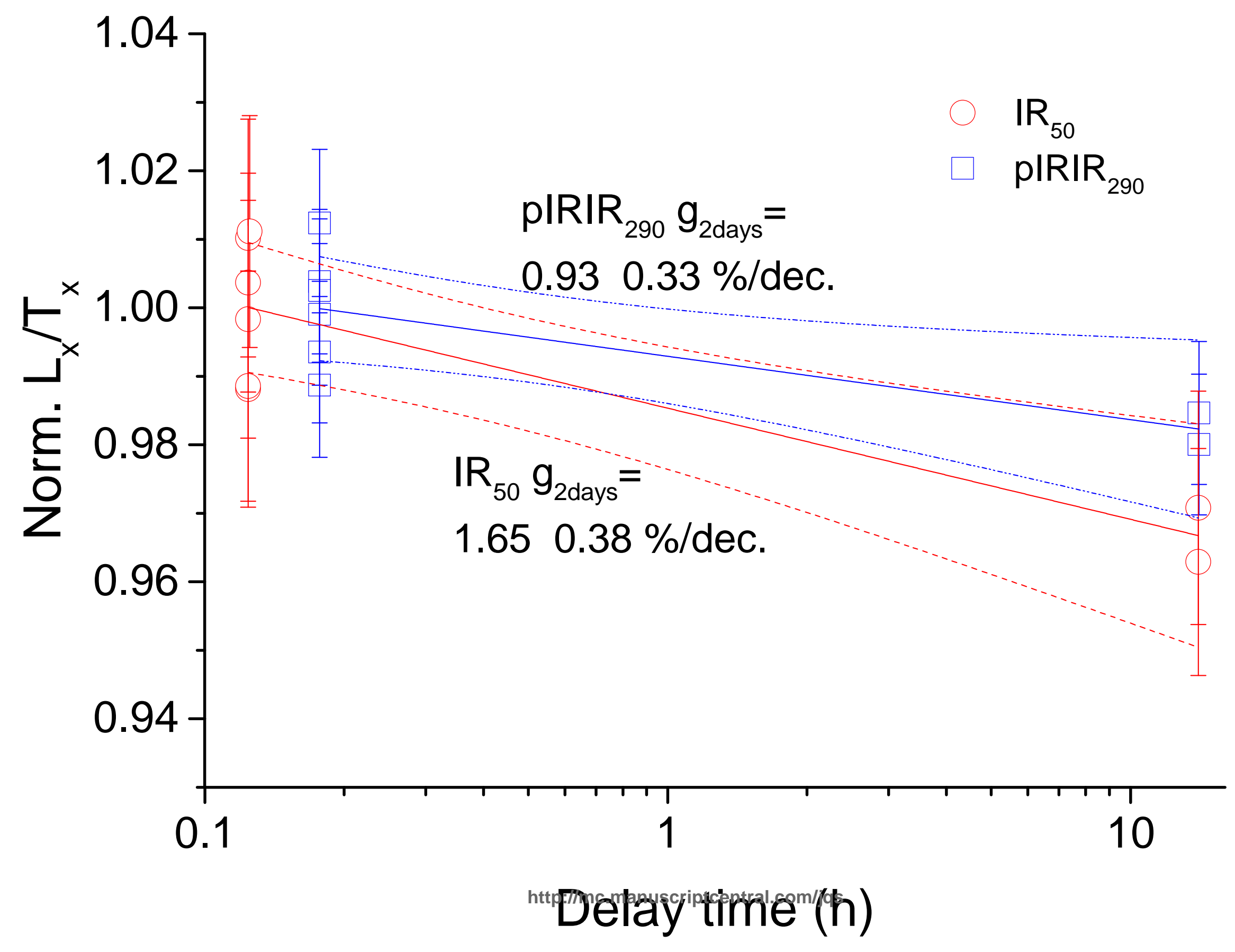




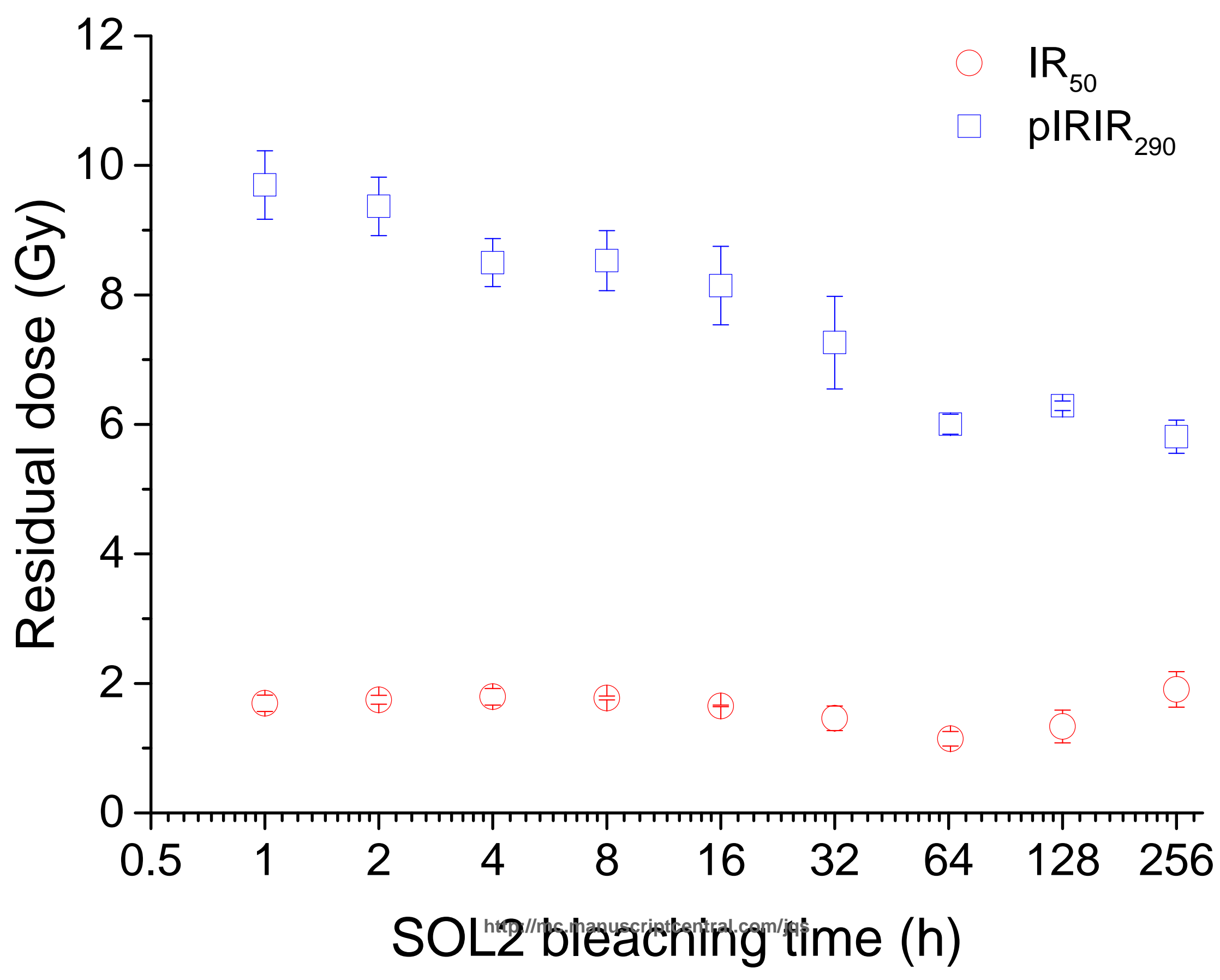




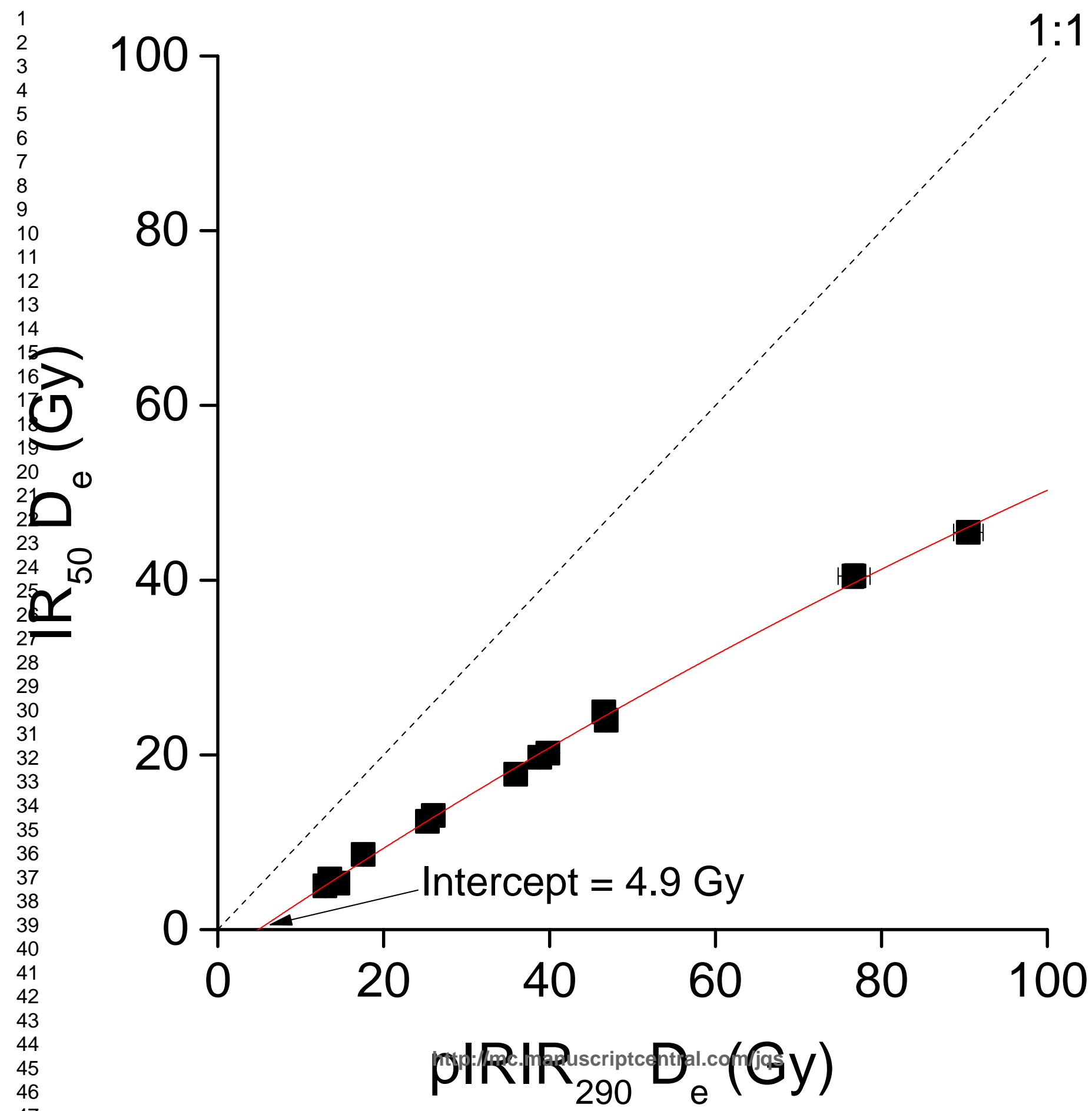


13 round surface at time of 14paleo-boulder emplacement

post-boulder loess colluvial wedge
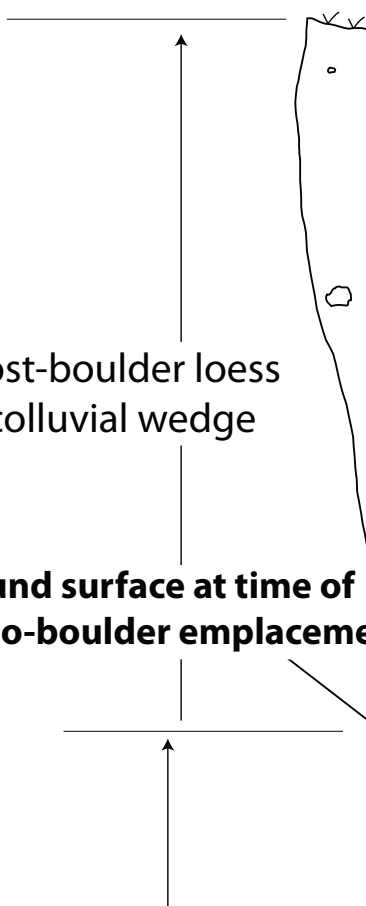

pre-boulder loess colluvium

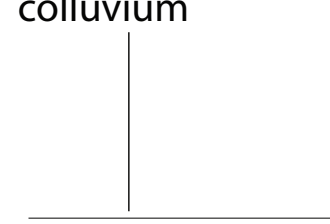

\section{t}

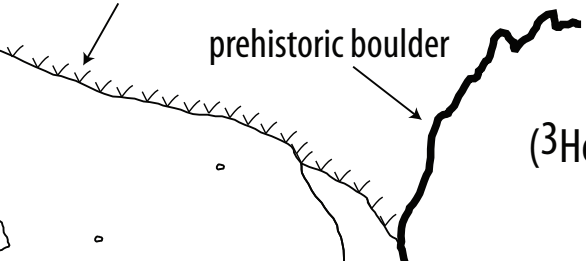

(3He Surface Exposure Age = 13 \pm 2.3 ka) 
